\title{
Honored in the Breech: Presidential Authority to Execute the Laws with Military Force
}

The recent assertions of an expanded presidential power ${ }^{1}$ to use military force domestically to execute the laws in peacetime ${ }^{2}$ have gone largely unnoticed, ${ }^{3}$ despite the vigorous debate over the related issues of inherent executive power to conduct undeclared wart and to im-

1. The Nixon Administration asserts the existence of an implicit constitutional authority to use military forces to protect federal property and functions, 37 Fed. Reg. 3637 (1972) (to be codified at 32 C.F.R. $\$ 215.4(\mathrm{c})(1)$ ). Contrary to previous administrations, the President does not interpret the Posse Comitatus Act, 18 U.S.C. $\$ 1385$ (1970) (discussed infra at pp. 141-46), as prohibiting the use of Marine Corps and Navy per: sonnel to enforce the law. Compare 37 Fed. Reg. 3637 (1972) (to be codificd at 32 C.F.R. $\$ 215.4(\mathrm{~b})$ ), wilh 32 C.F.R. $\$ 187.4(\mathrm{~b})$ (1971). On two occasions President Nixon cited the Economy Act of 1932, 31 U.S.C. $\$ 686$ (1970), as authority for using large numbers of troops to exccute the laws. See, e.g., Letter from Winton Blount to Melvin Laird, March 22, 1970, in Blaustein \& Koritzinsky, Law and the Military Establishment VI-107 (mimeograph, University of Wisconsin Law School, 1971). Both Presidents Johnson and Nixon have used H.R.J. Res. 1292, 90th Cong., 1st Sess. $\$ 2$ (1968), at 82 Stat. 170, 18 U.S.C.A. $\$ 3056$ notes $(1970)$, as authority for the use of troops to police anti-war demonstrations which might potentially harm the l'resident, Vice-President or major candidates for those offices, 37 Fed. Reg. 3638 (1972) (to be codificd at 32 C.F.R. $\$ 215.4(\mathrm{c})(2)(\mathrm{i})(\mathrm{d}))$. The Nixon Administration interprets 10 U.S.C. $\$ 333(1970)$ to permit it to use troops to execute state laws though there be no request by the governor or legislature, and though the enforcement of no federal laws be involved. Compare 37 led. Reg. 3638 (1972) (to be codified at 32 C.F.R. $\$ 215.4($ c)(2)(i)(c)), with 32 C.F.R. $\$ 187.4$ (c)(3)(i) (1971).

2. Presidents have used military force-Armed Scrvices, active Reserve Forces and federalized National Guard forces-to implement their constitutional duty to sce that the laws are faithfully executed, U.S. CoNsr. art. II, $\$ 3$, under the statutory authorizations of 10 U.S.C. $\$ 332$ (1970) and 10 U.S.C. $\$ 333$ (1970). The terms "execute" and "enforce" have been used interchangeably in this legislation. Compare Act of May 2, 1792 , ch. $28, \$ 2$, 1 Stat. 264, with Act of July 29, 1861, ch. 25, $\$ 1,12$ Stat. 28 $\overrightarrow{1}$, and 10 U.S.C. $\$ 332(1970)$.

A variety of actions have been taken under the rubric of execution of the laws: (l) Prevention of conduct prohibited by law, e.g., prevention of criminal activities during the 1968 riot in the District of Columbia. Proclamation No. 3840,3 C.F.R. 35 (1968). (2) Prevention of obstructions to the performance of the statutory dutics of government personnel, e.g., prevention of interference with the collection of federal revenues during the Whiskey Rebellion. Proclamation of September 25, 1794, set out in 1 J. Richardon, A Compilation of the Messages and Palers of the Presidents: 1789. 1897 , at 161 (1897) [hereinafter cited as Richardson]. (3) Enforcement of court orders. See, e.g., l'roclamation No. 3542, 3 C.F.R. 292 (1959-63) (compclling the integration of the University of Alabama). (1) The enforcement of treaty obligations. See, $\epsilon . g$. Message of President Cleveland to Congress, 8 Richardson 383 passim (protection of rights of Chinese laborers in Wyoming). (5) Execution of the general and inherent duties of government, e.g., use of troops to seize struck aviation plant. See B. RIcil, The Presidents and Civil Disorder $177-88$ (1941) [hereinafter cited as Rici1]. (6) Performance of duties of striking government workers in order to prevent their superior from violating his statutory duties. The only instance of this being done was President Nixon's authorization of the Postmaster General's use of military personncl to process and deliver mail during the 1970 postal strike in New York City. See Proclamation No. 3972, 3 C.F.R. 35 (1970).

3. See, e.g., Laird v. Tatum, 408 U.S. 1, 29 (1972) (App. I to opinion of Douglas, J., dissenting) which fails to list among the authorizations for domestic use of the military the inherent power theory; 31 U.S.C. $\$ 686(1970)$; and H.R.J. Res. 1292, at 82 Stat. 170 (1968).

4. See, e.g., Lofgren, War-Making Under the Constitution: The Original Under. standing, 81 YALE L.J. 672 (1972); Rostow, Great Cases Make Bad Law: The W'ar Powers Act, 50 Texas L. Rev. 833 (1972). 
pound funds and dissolve programs and agencies mandated by Congress. ${ }^{5}$ Presidents Johnson and Nixon, relying on a theory of inherent constitutional authority to use the military to fulfill their duty to see that the laws are faithfully executed, have ignored statutory restrictions on the use of military force in domestic affairs ${ }^{\mathfrak{b}}$ in committing troops to the streets on a number of occasions.

In October 1967 President Johnson used troops to protect the Pentagon from anti-war demonstrators. ${ }^{7}$ In May 1971 President Nixon used approximately 4,000 regular Army troops in Virginia and the District of Columbia to prevent demonstrators from disrupting traffic. ${ }^{8}$ In January 1973 Marine Corps personnel and equipment assisted the New Orleans police in suppressing a sniping incident. ${ }^{2}$ On none of these occasions was a proclamation to disperse ${ }^{10}$ issued as required by statute. Neither was there any formal statement by the Governor of Louisiana in the New Orleans incident requesting federal assistance nor a presidential statement that the state was denying the equal protection of the laws to citizens-as required by law. ${ }^{11}$

These circumventions of statutory procedures have had only minimal adverse consequences in the short run. However, their long-range effect on the separation of powers over the use of the military and on the accountability of the Executive is quite serious. One does not have to suspect the man in the White House of currying a white horse to find the current claim of such powers objectionable: A President who looks to Disraeli for inspiration may be succeeded by one who favors Cromwell. ${ }^{22}$ Moreover, a President with easy recourse to military force may

5. See, e.g., Note, Protecting the Fisc: Executive Impoundment and Congressional Power, 82 YALE L.J. 1636 (1972).

6. 10 U.S.C. $\$ 331(1970)$ permits the use of federal troops to execute state laws only on the request of the state legislature or governor. 10 U.S.C. $\$ 333(1)$ (1970) permits the use of federal troops to execute state laws only when specified activities also violate federal laws. 10 U.S.C. $\$ 334$ (1970) requires the issuance of a proclamation to disperse when troops are employed under 10 U.S.C. $\$ \S 331-33$. The Posse Comitatus Act, 18 U.S.C. $\$ 1385(1970)$, makes it a criminal offense willfully to use the Army or Air Force to exccute the law in cases or circumstances which are not expressly authurized by the Constitution or act of Congress. See Wrynn v. United States, $200 \mathrm{~F}$. Supp. 457,461 (E.D.N.Y. 1961); cf. Gillars v. United States, 87 App. D.C. 6, 182 F.2d 96. (D.C. Cir. 1950).

7. See ANnual Relort of til Secretary of the Army Fiscal Year 1968, at 156.

8. See Wash. Post, May 3,1971 , at 18 , cols. 2 \& 3.

9. See p. 144 infra.

10. 10 U.S.C. $\$ 334(1970)$.

11. I0 U.S.C. $\$ 334, \S 331$, and $\$ 333$ (1970), respectively. See pp. 139-41 infra.

12. Justice Frankfurter noted in his concurring opinion in Youngstown Sheet and Tube v. Sawyer:

The accretion of dangerous power does not come in a day. It does come, however slowly, from the generative force of unchecked disregard of the restrictions that fence in even the most disintercsted assertion of authority.

313 U.S. 549, 594 (1952) (concurring opinion). 
ignore conciliation, compromise, and understanding as responses to political dissent.

The relative powers of the President and Congress over the use of military force in domestic affairs is not a modern problem. A similar expansion of presidential authority during the Reconstruction ${ }^{13}$ led to the passage of restrictive legislation ${ }^{14}$ which sought to restore congressional control over the manner and circumstances in which military power could be used in domestic affairs. The impact of this legislation has been almost completely lost today. A reassertion of congressional authority is essential if the separation of powers over the military is to be restored. Such legislation should not prevent the President from making use of military force to preserve the peace in circumstances of extraordinary violence and disorder. However, requiring that the President take such actions openly, and publicly accept responsibility for them, will increase the political liabilities of the use of military force.

\section{Sources of Presidential Power to Use Troops Domestically}

\section{A. Inherent Power and the Constitution}

The scheme provided in the Constitution for the use of military force in domestic affairs was a compromise based on conflicting fears of national dominance, ${ }^{15}$ federal impotence, ${ }^{16}$ and military dictatorship. ${ }^{17}$ Although the evolution of political and military structures has undercut the guarantees against federal military hegemony over the states, ${ }^{18}$ the need for a balance between the power of the Executive to

13. See, e.g., ANNuAl Report of the Secretary of WAR (1877): "The Army is to the United States what a well-disciplined and trained police force is to a city . .." cited in 7 CoNG. Rec. 3582 (1878) (remarks of Mr. Kimmel).

14. 18 U.S.C. $\$ 1385(1970)$.

15. See, e.g., remarks of Colonel George Mason, in 1 M. Farrand, The Records of the Federal Convention of 1787, at 339 (1934) [hereinafter cited as Farrand]; and Patrick Henry, in 2 Ellor, Debates in the Several. State Conventrons 422-23 [hereinafter cited as ELLIOT].

16. The inability of the national government to protect its Springfield, Massachusetts, arsenal from seizure or to assist the Massachusetts government during Shay's Rebellion in 1787 (see Hill, The National Guard in Civil Disorders: Historical Prceedents, in BAYONETS IN THE STREETS 73 ( $R$. Higham ed. 1968) [hereinafter cited as BAYONETs]) was the "final argument to sway many Americans in favor of a stronger federal government." 1 S. Morison, H. Commager, W. Leuchtendurg, Growith of tile AMerican Rerublic 242 (6th ed. 1969). See also Letter from Elbridge Gerry to James Monroe, June 11,1787 , in 3 Farrand, supra note 15 , at 45 .

17. See, e.g., debate at 2 FARRAND 329-33, 385-88.

18. The Second Amendment protection against the disarming of militiamen by the federal government is relatively meaningless in an age of standardized military weaponry provided by the states. The ability of the national government to federalize a state's National Guard units which are members of the federal reserve in times of conflict between President and governor makes "states" rights" a political rather than 
respond to domestic violence with military force and the power of Congress to check excesses remains. ${ }^{19}$

To guard against the unrestrained use of military power by the Executive, Congress was given the power to organize, arm and discipline the militia ${ }^{20}$ (now the National Guard ${ }^{21}$ ), to provide for calling forth the militia to execute the laws of the United States, ${ }^{22}$ to raise and support the regular military forces, ${ }^{23}$ and to make rules for the government and regulation of the land and naval forces. ${ }^{24}$ And although the President was made commander in chief of the armed forces ${ }^{25}$ and required to see that the laws were faithfully executed, ${ }^{26}$ the net effect of these constitutional provisions was the "policy that Congress, not the Executive, should control utilization of the war power as an instrument of domestic policy."27 Nevertheless the argument persists that the President has an inherent power to execute the laws with military force. The current Administration states simply that the President may use military forces domestically without heeding statutory requirements, asserting:

The President has the inherent power and the duty under the Constitution as Chief Executive to insure the continued functioning of the government and to protect the government's property. ${ }^{28}$

a military term. See, e.g., Proclamation No. 3204, 3 C.F.R. 132 (1954-1958 Comp.), federalizing the entire Arkansas National Guard during the Little Rock school crisis of 1957, even though all of the troops were not needed for federal duty.

The guarantee contained in 10 U.S.C. $\$ 331$ (1970) that the President will not call up the National Guard of a state requesting federal assistance (see remarks of James Mladison and George Nicholas at the Virginia ratifying convention, 3 Elcior, supra note 15, at $425-27$ ) has been eliminated by the simple expedient of utilizing I0 U.S.C. is 332-33. See, e.g., Proclamation No. 3795, 3 C.F.R. 68 (1967), federalizing the Michigan National Guard because of "domestic violence... obstructing the execution of the laws of the United States, including the protection of federal property in the City of Detroit."

19. As Justice Brandeis noted in his dissenting opinion in Myers v. United States: The doctrine of the separation of powers was adopted ... not to promote efficiency but to preclude the exercise of arbitrary power. The purpose was not to avoid friction, but, by means of the inevitable friction incident to the distribution of the governmental powers among three departments, to save the people from autocracy.

272 U.S. 52, 293 (1926).

20. U.S. CoNsT. art. I, $\$ 8, \mathrm{cl} .16$.

21. Dick Act of 1903, 10 U.S.C. $\$ 3501$ (1970).

22. U.S. Consr. art. I, $\$ 8, \mathrm{cl}$. 15 .

23. Id. at cls. $12 \& 13$.

24. Id. at cl. 14 .

25. Id. at art. II, $\$ 2$.

26. Id. at art. II, $\$ 3$.

27. Youngstown Sheet and Tube v. Sawyer, 343 U.S. 579, 644 (1952) (Jackson, J., concurring).

28. Letter from the Justice Department, quoted in E. CoRwin, ThE Constitution 149-50 (13th cd. 1973) [hereinafter Conwin (1973)]. For a similar formulation see 37 Fed. Reg. 3637 (1972) (to be codified at 32 C.F.R. $\$ 215.4(\mathrm{c})(1)$ ). See also Message of president Fillmore to the Senate, 5 Richardson 104; Furman, Restrictions on the Use of the Army Imposed by the Posse Comitatus Act, 7 MIL. L. REv. 85, 87.92 (1960). 
For example, the Department of Defense claims that this principle exempts the Executive from the restrictions of the Posse Comitatus Act, ${ }^{29}$ which previously had been interpreted to make criminal the willful use of the Army and Air Force "to execute local, State or Federal laws except as Congress may authorize."30 The current statement of policy also deletes the ruling of the Johnson Administration that the Posse Comitatus Act is applicable to the Navy and Marine Corps. ${ }^{31}$

The Department's inherent power theory finds apparent support in the case of In re Neagle. ${ }^{32}$ There the Supreme Court upheld the action of a federal marshal in defending a Supreme Court Justice from assault, despite the fact that such an assault was not then a federal crime, and no legislation authorized such a protective detail. The Court held that the "laws" a President is bound faithfully to execute include not only acts of Congress and treaties of the United States but also

the rights, duties, and obligations growing out of the constitution itself, our international relations, and all the protection implied by the nature of the government under the constitution . . . . ${ }^{33}$

Using such a theory President Taft argued that a President possesses inherent power ${ }^{34}$ to use troops to protect aliens whose security was guaranteed by treaty, even though no federal criminal laws would be violated by assailants of the aliens. ${ }^{35}$ In fact, prior to the authorization of the use of regular military forces to execute the laws in 1807, the first three Presidents utilized regular army forces on the basis of their inherent authority. ${ }^{36}$ Similar reasoning has been employed to find an

29. 18 U.S.C. $\$ 1385$ (1970), discussed at pp. 141-46 infra.

30. 32 C.F.R. $\$ 187.4(\mathrm{~b})(1971)$.

31. Compare 37 Fed. Reg. 3637 (1972) (to be codified at 32 C.F.R. $\$ 215.4(b)$ ), will 32 C.F.R. \$187.4(b) (1971). "Although the Navy and Marine Corps are not expressly included within its provisions, the act is regarded as national policy applicable to all military services of the United States."

32. 135 U.S. I (1890).

33. Id. at 64 .

34. This has been termed as an "aggregate of the President's powers" (Attonney" General Jackson, 1941, in RICH, supra note 2, at 181), a "Stewardship Theory" (E. CoRWin, The President: OfFice ANd Powers, 1787-1957, at 147-58 (1957), and as the power of the President as Head of State, as opposed to Chief Executive (Intersicw with Eugene V. Rostow, September 17, 1973).

35. W. TAFT, THE PREsidency 83 (1916).

36. See 6 Naval Documents Related to the United Sranes Wars wini tile Bakbiky Prrates 315 (use of troops by President Jefferson to protect representative of Bey of 'Tunis); 12 The Papers of Alexander Hamilton 552 (H. Syrett ed. 1967) (use of troops by President Washington to protect revenuc officer); 1 RICHARDson, supra note 2, at

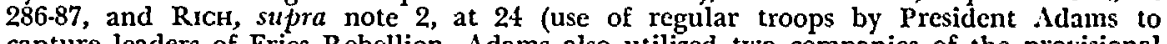
capture leaders of Fries Rebellion-Adams also utilized two companies of the provisional 
implicit executive duty to protect federal property. ${ }^{37}$

The holding in Neagle, however, is confined to the situation where Congress has neither explicitly nor impliedly spoken on presidential power to protect federal property or the functions of government. Youngstown Sheet and Tube v. Sawyer ${ }^{38}$ supports this interpretation. In the course of holding that executive authority to seize the steel mills did not exist, Justice Black, writing for the Court, emphasized that Congress has "exclusive authority to make laws necessary and proper to carry out the powers vested by the Constitution in the Government of the United States, or any Department or Officer thereof." "39 Executive authority not expressly granted by the Constitution, the Court indicated, can be nothing but the creature of statute, and as such, the power can extend no further than the limits expressed in any statute creating such authority.

Justice Black's majority opinion, however, may not conclusively resolve the issue of inherent powers. The holding of Youngstown may turn on the more cautious and limited concurring opinions of Justices

army, Act of May 28, 1798 , ch. 47 , I Stat. 558 , but this use was not authorized by the statute, id. at $\$$ 1); 1 Richardoson, supra note 2, at 404 (use of regular troops by President Jefferson to capture Aaron Burr).

In 1885 President Cleveland sent troops to protect Chinese laborers after a massacre in Wyoming, 8 Richardson 385, and F. Wilson, Federal Aid in Domestic Disturbances 187, S. Doc. No. 263, 67th Cong., 2nd Sess. (1922). However, President Cleveland subsequently rejected an inherent power theory as an authorization for such action, see F. Wilson, supra, at 298, and later issued a proclamation when he sent troops into the Washington Territory to protect Chinese laborers in 1886. See id. at 186, 298; 8 RichaRDSON 488.

37. 9 Or. ATr'y GEN. 520-21 (1860). See, e.g., Rich, supra note 2, at 70 (use of troops to protect federal Mint in San Francisco in 1851 during Vigilante disturbances); IF. WilsoN, supra note 36 , at 171,284 (protection of federal property in Illinois and Indiana during 1877 railroad strike); $\mathrm{RICH}$, supra note 2, at 167-76 (dispersal of Bonus March). Other presidents felt that such use of troops required the issuance of a proclamation, since action was taken on the basis of the predecessor to 10 U.S.C. $\$ 332$ (1970): see F. W'iLson 84 (provision of proclamation to Col. Robert $\mathrm{E}$. Lee to be read at Harper's Ferry in 1859. But see B. NAlty, Unired States Marines AT Harper's FerRY 3.4 (U.S. Marine Corps pamphlet, 1966) (Lee declined to read the proclamation to disperse when he saw that John Brown and his body of saints had already been surrounded in the federal arsenal at Harper's Ferry)).

A distinction can be made between the protection of federal property and functions. The former stems from the ability of the national government to legislate and regulate conduct within federal enclaves, U.S. Consr. art. I, $\$ 8$, cl. 17. The national government may have full responsibility for the property, as in the District of Columbia; there may be a division of responsibility, see Collins v. Yosemite Park and Cury Co., 304 U.S. 518, 528 (1938); James v. Dravo Construction Co., 302 U.S. 134, 142 (1937); cf. State v. District Court, 147 Mont. 151, 410 P.2d 459 (1966), or the federal government may decline jurisdiction, thereby leaving responsibility for regulating conduct within the enclave to the state, see Unitcd States v. Pate, 393 F.2d 44 (7th Cir. 1968), cert. denied, 393 U.S. 890 (1969); 40 U.S.C. $\$ 255$ (1970). Protection of federal chattels has becn bottomed on a common law theory, see In re Debs, 158 U.S. 564, 584 (1895). Protection of fcderal functions is a permutation of the duty to see that the laws are faithfully executed, see 18 U.S.C. $\$ 232(3)(1970)$, and In re Neagle, 135 U.S. 1, 59 (1890). 38. 343 U.S. 579 (1952).

39 . 343 U.S. at 588-89, quoting U.S. ConsT. art. I, § 8. 
Frankfurter, ${ }^{40}$ Jackson, ${ }^{41}$ and Clark. ${ }^{42}$ Even these opinions, however, settle any doubts that inherent power is a narrowly confined notion. ${ }^{43}$ When Congress has not taken any action, presidential interpretation of the Executive's Article II authority is relatively strong, and "is likely to depend on the imperatives of events and contemporary imponderables ...." 44 For example, in Neagle there was no legislation either authorizing or restricting the President's action in protecting the Supreme Court Justice.

But when Congress has acted in a legitimate exercise of its Article I powers so as to "cover the field," and in the course of doing so restricts or qualifies the President's general freedom of action, the Executive may not circumvent the legislatively established procedures. ${ }^{45}$ Justice Jackson's concurring opinion in Youngstown does admit that situations may exist where the President can ignore a congressional mandate, but this will only be true when the Executive's Article II powers are so strong that the Court could justify "disabling the Congress from acting upon the subject." ${ }^{46}$ The only Article II powers relevant to the present inquiry are the President's authority as commander in chief, ${ }^{4 \tau}$ and to "take care that the laws be faithfully executed." 48 Neither of these provisions sustains exclusive presidential control. The commander in chief clause is inapposite, since that is a war power not intended to apply to internal affairs, ${ }^{49}$ particularly when there is no "public war." 50 And the execution clause only means that the President may take such actions as are necessary to protect the federal government if those measures are not forbidden or circum-

\author{
40. Id. at 593-614. \\ 41. Id. at 634-55. \\ 42. Id. at 660-67. \\ 43. See also Brandeis, J., dissenting in Myers v. United States, 272 U.S. 52, 246-47 \\ (1926): \\ There is no express grant to the President of incidental powers resembling those \\ conferred upon Congress by clause 18 of Article I, $\$ 8$. A power implied on the \\ ground that it is inherent in the executive, must, according to established prin- \\ ciples of constitutional construction, be limited to "the least possible power adequate \\ to the end proposed." ... The end to which the President's efforts are to be \\ directed is ... the faithful execution of the laws consistent with the provisions \\ therefor made by Congress. \\ 44. 343 U.S. at 637 (Jackson, J., concurring). \\ 45. Id. at 602 (Frankfurter, J., concurring) and 637-38 (Jackson, J., concurring). \\ 46. Id. at $637-38$. \\ 47. U.S. Const, art. II, $\S 2(1)$. \\ 48. Id. $\$ 3$. \\ 49. 343 U.S. at 587 (opinion of the Court), 632 (Douglas, J., concurring), 644 (Jackson, \\ J., concurring), 650 (Burton, J., concurring), and 660-61 (Clark, J., concurring). \\ 50. Cf. Prize Cases, 67 U.S. (2 Black) 635, 666 (1862); CoRwiN (1973), supra note \\ 28 , at $120-23$.
}




\section{Presidential Authority to Execute the Laws with Military 'Force}

scribed by Congress. ${ }^{51}$ Where Congress has acted the President is clearly required to remain within the legislative bounds. ${ }^{52}$

Thus the relevant inquiry is whether Congress has given the President all the power he needs to fulfill his responsibility to execute the laws. If it has, then no power vacuum exists, and the question of inherent presidential authority does not arise. Any executive attempt to circumvent statutory procedures would clearly be unjustifiable. ${ }^{63}$

\section{B. The Statutory Framework}

Although the theory of inherent presidential power to use troops to protect federal property and federal functions may have been valid at one time, ${ }^{54}$ it has been vitiated by congressional authorizations and restrictions on the use of troops to execute the laws, and by the passage of explicit federal legislation prohibiting a wide range of conduct damaging to federal interests. ${ }^{55}$

Congress pursuant to its constitutional authority has provided a broad range of legislation authorizing the President to use regular and federalized militia forces to execute the laws. The President is currently empowered to use such forces to respond to requests for assistance from state governments, ${ }^{56}$ to enforce the laws of the United States, ${ }^{57}$ to protect the rights of persons within the states when both

\section{See Corwin (1973), supra note 28, at 149:}

Because of his duty "to take care that the laws be faithfully executed," the President has the right to take any necessary measures which are not forbidden by statute to protect against impending danger those great interests which are entrusted by the Constitution to the National Government (emphasis added).

52. See 343 U.S. at 633 (Douglas, J., concurring) ("[A]s Mr. Justice Black and Mr. Justice Frankfurter point out, the power to execute the laws starts and ends with the laws Congress has enacted."). See also id. at 587 (Black, J., opinion of the Court), 610 (Frankfurter, J., concurring), 641, 653 (Jackson, J., concurring), 660 (Burton, J., concurring), and 660-61 (Clark, J., concurring); note 43 supra.

53. See p. 138 infra. The citation of In re Debs, 158 U.S. 564 (1895), in this context is inapposite, since the President had issued a proclamation while using troops to enforce a court order against various actions taken by striking railroad workers, 9 Richardsox, supra note 2, at 499, properly basing his action on the authorization of the predecessors of 10 U.S.C. $\$ \$ 332$ and $333(1970)$.

54. See note 36 supra.

55. See, e.g., 18 U.S.C. \$ 231 (1970) (prohibiting participation in civil disorders which affect commerce or federal functions). See also p. 138 infra.

56. 10 U.S.C. $\$ 331(1970)$ :

Whenever there is an insurrection in any State against its government, the President may, upon the request of its legislature or of its governor if the legislature cannot be convened, call into Federal service such of the militia of the other States, in the number requested by that State, and use such of the armed forces, as he considers necessary to suppress the insurrection.

57. 10 U.S.C. \$ 332 (1970):

Whenever the President considers that unlawful obstructions, combinations, or assemblages, or rebellion against the authority of the United States, make it impracticable to enforce the laws of the United States in any State or Territory by the ordinary course of judicial proceedings, he may call into Federal service such of the militia of any State, and use such of the armed forces, as he considers necessary to enforce those laws or to suppress the rebellion. 
state and federal laws are obstructed, ${ }^{58}$ to reinforce the Secret Service in protecting the President and Vice-President and major candidates for those offices, ${ }^{59}$ and to meet specified contingencies. ${ }^{60}$ It has also enacted explicit legislation to protect federal property from destruction $^{61}$ and has established regulations governing conduct within federal enclaves. ${ }^{62}$

Congress has also mandated a number of restrictions on the manner and circumstances in which troops can be used. With one exception, ${ }^{b 3}$

58. 10 U.S.C. $\$ 333$ (1970):

The President, by using the militia or the armed forces, or both, or by any other means, shall take such measures as he considers necessary to suppress, in a State, any insurrection, domestic violence, unlawful combination, or conspiracy, if it-

(I) so hinders the execution of the laws of that State, and of the United States within the State, that any part or class of its people is deprived of a right, privilege, immunity, or protection named in the Constitution and secured by law, and the constituted authorities of that State are unable, fail, or refuse to protect that right, privilege, or immunity, or to give that protection; or (2) opposes or obstructs the execution of the laws of the United States or impedes the course of justice under those laws.

In any situation covered by clause (1), the State shall be considered to have denied the equal protection of the laws secured by the Constitution.

59. H.R.J. Res. 1292, at 82 Stat. 170 (1968).

60. The laws which specify the contingencies are now anachronisms, since the same purposes would be met by action taken under 10 U.S.C. $\$ 332$ (1970) (see note 57 supra): 50 U.S.C. $\$ 205$ (1970) (corresponds to Act of July 13, 1861, ch. 3, $\$ 5$, 12 Stat. 257) (providing for use of military to end intercourse with States in insurrection); 50 U.S.C. $\$ 220$ (1970) (corresponds to Act of July 13, 1861, ch. 3, $\$ 3,12$ Stat. 256) (providing for use of military force to assist customs officers in enforcing a blockade of insur. rectionary States); 16 U.S.C. $\$ 23$ (1970) (corresponds to Act of March 3, 1883, ch. 143, 22 Stat. 627) (providing for use of troops to protect Yellowstone National Park); 16 U.S.C. $\$ 78$ (1970) (corresponds to Act of June 6, 1900, ch. 791, 31 Stat. 618) (providing for use of troops to protect Sequoia and Yosemite National Parks); 16 U.S.C. \$ 593 (1970) (corresponds to Act of February 23, 1822, ch. 9, 3 Stat. 651) (providing for use of troops to prevent cutting federal timber in Florida); 43 U.S.C. $\$ 1065$ (1970) (corresponds to Act of February 25, 1885, ch. 149, $\$ 5,23$ Stat. 332) (providing for use of troops to remove or destroy unlawful enclosures on specified public lands); 22 U.S.C. $\S 462$ (1970) (corresponds to Act of April 20, 1818, ch. 88, $\S 9,3$ Stat. 449 ) (providing for use of military force to compel a ship to depart American waters); 22 U.S.C. $\S 408$ (1970) (corresponds to Act of June 15, 1917, ch. 30, $\$ 8,40$ Stat. 225) (providing for use of military force to prevent exportation of war materiel in circumstances which would violate American neutrality); 42 U.S.C. $\$ 97$ (1970) (correspond4 to Act of February 23, 1799, I Stat. 619) (providing for use of troops to enforce quaran. tine laws); 25 U.S.C. $\$ 180$ (1970) (corresponds to Act of June 30, 1834, ch. 161, $\$ 11$, 4 Stat. 730) (providing for use of military force to protect Indians from settlers on specified territory); 48 U.S.C. $\$ 1418$ (1970) (corresponds to Act of August 18, 1856, ch. $164, \S 5,11$ Stat. 120) (providing for use of troops to protect the rights of citizen who claims a guano island).

61. See, e.g., 18 U.S.C. $\$ 1361$ (1970).

62. 40 U.S.C. $\$ 318(a)$ (1970), see United States v. Cassiagnol, 420 li.2d 868 (14h Cir.), cert. denied, 397 U.S. 1044 (1970); Assimilative Crimes Act of 1948, 18 U.S.C. 13 (1970). See also United States v. Sharpnack, 355 U.S. 286 (1958); 18 U.S.C. \$ 1382 (1970).

63. 18 U.S.C. $\$ 592$ (1970) (corresponding to Act of February 25, 1865, ch. $52, \$ 1$, 13 Stat. 437) prohibirs a federal officer from keeping troops at a polling place unles they are required "to repel armed enemies of the United States." The provision of the 1865 act which permitted their use to "keep peace at the polls" was deleted by the Act of March 4, 1909, ch. 321, $\$ 22,35$ Stat. 1092. In 1879 President Hayes had vetoed a similar attempt to amend the law because it would have prohibited him from responding to a state request for assistance in suppressing domestic violence in the vicinity of polling places, 7 Richardson, supra note 2, at 523 . The current word- 
these restrictions pose no serious operational impediments to the use of military force to execute the laws. If disorder significantly threatens the enforcement of federal laws or the fulfillment of federal duties, no statutory restrictions stand in the way of swift military action on the part of the President.

\section{Enforcement of State Laws}

Congress has stipulated that the President may intervene with military force to execute state laws only on the request of the state legislature, or of the governor when the legislature is not in session. ${ }^{64}$ During the debate over the Ku Klux Klan Act in 1871, ${ }^{65}$ Congress specifically rejected an authorization for federal intervention to execute state laws without such an invitation when no federal laws were being violated and when no denial of Fourteenth Amendment rights

ing of the provision cannot be harmonized with the Guarantec Clause, U.S. ConsT. art. IV, $\$ 4$, and hence it is an improper limitation on the President's power. Following this reasoning, the current administration does not interpret 18 U.S.C. $\$ 592$ as a valid prohibition of such a use of troops. See W. Schlotterbeck AND A. MANSINNE, ThE Role of the Departient of Defense in Civil Disturbances 31 (Industrial College of the Armed Forces pamphlet, 1970).

Other disabling restrictions on the President's ability to use troops to respond to grave emergencies have been repealed. The original version of 10 U.S.C. $\$ 332$ (1970), Act of May 2, 1792, ch. 28, $\$ 2$, I Stat. 264, required that the President call forth the militia only after being notified by an Associate Justice or District Judge that the laws could not be enforced. This restriction was dropped when the law was amended, Act of February 28, 1795, ch. $36, \S 2$, I Stat. 424 . A requirement of the initial legislation that the President turn to Congress, if it were in session, for permission to call up the militia, was also deleted in the 1795 legislation. Similarly, the Act of May 2, 1792, \$2, I Stat. 264, required the President to request permission from Congress to maintain the militia in federal status for more than thirty days after the commencement of the next session of Congress. See, e.g., Act of November 29, 1794, ch. I, I Stat. 403. In 1861 the period was extended to 60 days, Act of July 29, 1861, ch. $25, \S 3,12$ Stat. 282. The current law, 10 U.S.C. $\$ 3501$ (1970), provides that the President may specify the period of service. Section 2 of the 1792 legislation also limited the President to use of the militia of the "state or states most convenient" to the disorder, 1 Stat. 264. This requirement was deleted in 1795 .

On two occasions the power of the President to use troops was specifically limited by Congress. In 1809 Congress repealed the authority it had provided President Jefferson to use troops, without a proclamation, to execute the Embargo Acts, Act of January 9 , 1809, ch. 5, $\$ 11,2$ Stat. 510, as amended, Act of March 1, 1809, ch. 24, \$ 1, 2 Stat. 528. During the Nullification controversy, Congress briefly reinstated the requirement that the President use troops only after being notified by a member of the federal judiciary of obstructions to the law, Act of March 2, 1833, ch. $57, \S 5,4$ Stat. 634.

61. 10 U.S.C. $\$ 331(1970)$. The power to enforce state laws certainly is one of those reserved to the states by the Tenth Amendment.

65. Act of April 20,1871 , ch. $22, \S 3,17$ Stat. 13 (codified at 10 U.S.C. $\$ 333$ ); CoxG. Glone, 42nd Cong., Ist Sess. 567, 703 (I871) (remarks of Sen. Edmunds). Although serious civil disturbances might provide the requisite obstructions to both state and federal laws stipulated in 10 U.S.C. $\$ 333(1)(1970)$, a proclamation is required, thus preventing the covert use of the federal military to enforce local laws. Official Department of Defense policy purports to follow the restriction of 10 U.S.C. $\$ 333(1)$, see 37 Fed. Reg. 3639 (1972) (to be codified at 32 C.F.R. $\$ 215.9(a)(2)$ ). But see p. 147
infra. 
of citizens was involved. This restriction supports the policy of placing the responsibility for enforcement of local laws on the states and their subdivisions. Only when federal laws are involved or when the inaction of local law enforcement officials leads to infringement of the rights of citizens is the President authorized to utilize the military in such a role. ${ }^{00}$ The Nixon Administration's position that intervention is permissible when only state laws are being violated ${ }^{67}$ ignores the wording of the act itself and the express intent of Congress in passing it.

If military intervention were permitted on the volition of the President or a request from a local official, the authority of governors and state legislatures would be significantly undermined. ${ }^{\circ s}$ The requirement of a request by a governor or legislature also serves the purpose of alerting the voters of a state to inadequacies in local law enforcement agencies or the failure of local officials to resolve conflicts short of military force.

\section{Proclamation to Disperse}

The President has been required since $1792^{69}$ to issue a proclamation ordering "the insurgents to disperse and retire peaceably to their abodes within a limited time"70 whenever troops were used pursuant to 10 U.S.C. $\$ \$ 331-33$ and predecessor statutes. The intent of Congress with respect to the proclamation requirement is not evident from the records of the debates. ${ }^{71}$ However, it was probably meant as a

66. 10 U.S.C. $\$ 333(1970)$.

67. Compare 10 U.S.C. $\$ 331(1)$ (1970) ("laws of that State, and of the United States within the State..."), with 37 Fed. Reg. 3638 (1972) (to be codified at 32 C.F.R. \$ 215.4(c)(2)(i)(c)) ("execution of State or Federal law . . .") (emphasis added). 68. See generally B. Marshall, Federalism aNd Civil Rights (1964).

69. Act of May 2, 1792, ch. 28, § 3, 1 Stat. 264.

70. 10 U.S.C. $\$ 334(1970)$.

71. See 3 ANNALS of CoNc. 577 (1792). 10 U.S.C. $\$ 334$ (1970) is not a "riot act" since it imposes no criminal penalty for failure to disperse. It is also not a declaration of martial law, since federal troops act under the command of a "Senior Civilian Representative of the Attorney General" who is in close touch with the President at all times, sec SchlotrieribeK and Mansinne, supra note 63 , at 31 . The role of the military is limitcd to assisting civil authorities. Persons apprehended by the military are turned over to civil authorities for trial, 32 C.F.R. \$501.1(c) (1973). Although the prescribed proclamation speaks of the dispersal of "insurgents," it was not intended merely to apply to mobs or massed resistance to the law. For example, when President Jefferson uscd troops to execute the provisions of the Embargo Act, supra note 63, they assisted in searching ships and patrolling ports and waterways, see RICH, supra note 2, at 31-34. President Fillmore asked that the proclamation requirement be eliminated since its usc seemed inappropriate in providing military assistance to marshals sceking to recapturc escaped slaves. 5 RichaRDSON, supra note 2, at 105. Congress however refused to eliminate the proclamation for stich uses of troops. Fillmore's successor, President Pierce, was consequently forced to use other means to avoid issuing such proclamations, see pp. 142-43 infra and accompanying notes. See also 16 Op. ATr'Y GeN. 162 (1878). In modern times both Presidents Kennedy and Johnson used proclamations in circum- 
means of suppressing opposition to the laws with the authority of the presidency and the threat, rather than the use, of arms. ${ }^{72}$ Additionally, there was some sense that citizens should be alerted to the prospect of military intervention.

The proclamation also compels the President to acknowledge his responsibility for the use of troops in a civil context. ${ }^{73}$ This requirement prevents the covert use of military forces in law enforcement roles in the civilian sector. At the same time, it forces the President to accept the political risks of such intervention and the implicit admission that he failed to resolve the disorder with the civil resources of the government. Hence it serves to limit such uses of military force to situations grave enough to overcome presidential political caution.

\section{The Posse Comitatus Act}

The Posse Comitatus Act ${ }^{7 *}$ limits the ability of the President to circumvent requirements, such as that for a proclamation to disperse, by declaring:

Whoever, except in cases and under circumstances expressly authorized by the Constitution or Act of Congress, willfully uses any part of the Army or Air Force as a posse comitatus or otherwise to execute the laws shall be fined not more than $\$ 10,000$ or imprisoned not more than two years, or both.

The Act has been interpreted as a prohibition against the use of the Army or Air Force, ${ }^{75}$ either as part of a posse comitatus $^{76}$ or in a military role other than as provided by statute, ${ }^{77}$ to assist local law

stances in which no mobs were on the streets, using the proclamations to urge obedience to the laws and providing notice of their use of troops to execute court orders, Proc. No. 3542, 3 C.F.R. 292 (Comp. 1959-1963) and Proc. No. 3645, 3 C.F.R. 102 (Comp. 1964-1965).

72. See remarks of Edmund Randolph, then Attorney General, that the proclamation was a "merely humane and prudent caution," the purpose of which was "to prevent if possible, bloodshed in a conflict of arms, and if this cannot be done, to render the necessity of it palpable, by a premonition to the insurgents to disperse and go home," cited in RICH, supra note 2, at 206. See also Letter of Gcorge Washington to Alexander Hamilton, September 17, 1792, in 12 Tiue PAiers of Alexander HaMilton 308 (H. Syrett ed. 1967).

73. Cf. 7 CoNG. REC. 4243 (remarks of Senator Merrimon) and 4648 (remarks of Senator Sergeant) (1878).

7.1. 18 U.S.C. $\$ 1385$ (1970).

75. The Act originally applied only to the Army, Act of June 18, 1878, ch. 263, $\$ 15,20$ Stat. 152. In 1956 the Air Force was added during the general re-writing of legislation to take into account the creation of the Department of the Air Force, Act of August 10,1956, ch. 1041, $\$ 18(a), 70 \mathrm{~A}$ Stat. 626, see Furman, supra note 54, at 96. 76. The population of a county above age fifteen which a sheriff or marshal may summon to his assistance in certain circumstances, see Engdahl, Soldiers, Riots and
Revolution: The Law and History of Military Troops in Civil Disorders, 57 IA. L. REv. 2.10 (1971).

77. Wrynn v. United States, 200 F. Supp. 457, 464 (E.D.N.Y. 1961). 
enforcement officers in carrying out their duties. The same prohibition runs against the use of troops to execute federal laws. ${ }^{78}$ However, given the broad authorizations for the use of troops to execute the laws, ${ }^{79}$ the effect of the Act is limited to making criminal the willful omission of the proclamation required by 10 U.S.C. $\$ 334$ when Army or Air Force personnel are involved, ${ }^{80}$ or the provision of such troops to assist local officials without the request of a governor or legislature. ${ }^{81}$

The Act requires that the Army and Air Force be used to execute the laws only on the basis of an express statutory authorization. This provision was directed against the use of troops in a marshal's posse under the implicit authorization of the statutes granting him the same powers as a sheriff, i.e., the power to summon citizens to his aid..$^{22}$ This practice had begun in $1854^{83}$ as a means of circumventing the proclamation requirement during the bitter political struggle over the enforcement of the Fugitive Slave Act ${ }^{84}$ in the North. Following the Civil War wide use was made of the military posse for law enforcement activities under the control of federal marshals, ${ }^{85}$ federal officers $^{86}$ and sheriffs. ${ }^{87}$

In the debate over the Act a number of practices were cited as abuses: the use of troops by federal officials to guard returning boards during the 1876 presidential election; 88 the deleterious effect of the practice on the command structure of the Army; ${ }^{80}$ the widespread use of such troops to assist revenue officers in destroying illegal stills; ${ }^{; 0}$ and the use of troops, without presidential authorization, to assist in

78. 4I Op. ATr'Y Gen, 330 (1957); 16 OP. ATT'Y GEN. 162 (1878).

79. See pp. 137-39 supra.

80. See E. Corwin, The President: Office and Powers 175 (1918). Sec also 7 Cong. REC. 4243 (1878) (remarks of Sen. Merrimon).

81. 16 OP. ATT'Y GEN. 162 (1878).

82. Act of May 2, 1792, ch. 28, $\$ 9,1$ Stat. 265; Act of September 24, 1789, ch. 20, $\$ 27$, I Stat. 87 .

83. 6 OP. ATr'Y GeN, 466 (1854). See Message of President Fillmore to Congress, in 5 Richardson, supra note 2, at 10I; Letter of Ed̈mund Randolph to Alexander Hamilton. 12 The Papers of Alexander Hamilton 34 (H. Syrett ed. 1967). But see Engdahl, supra note 77 , at 49 (assertion that troops had been used in posses since 1792).

84. Act of September 18, 1859 , ch. 60, 9 Stat. 462 .

85. See Davis, The Federal Reconstruction Acts, in Studies in Souturnx History ANd Politics 214 (1914); J. Sefton, The United States ArMY and Reconstruction, $1865-1877$, at $228(1967)$.

86. Troops were used extensively against illegal distilleries under the command of revenue officers, see High, The Marine Corps and Crowd Control, in BaYonets, supra note 16, at 119; N.Y. Times, Jan. 13, 1871, at 3, col. 2; id., Jan. 14, 1871, at 3, col. 2; and 7 CoNG. REc. 3581 (1878) (remarks of Mr. Kimmel).

87. See 7 Cong Rec. 3581 (1878) (remarks of Mr. Kimmel).

88. See 7 Cong. REc. 3850, 4185 , \& 4240 (1878) (remarks of Sens. Southard, Merrimon, and Kernan).

89. Id. at 4241 (remarks of Sen. Sargent).

90. Id. at 4248 (remarks of Sen. Hili). 
the suppression of a labor dispute. ${ }^{11}$ Criticism of the general practice by military leaders was also cited.92

The reasons for the passage of the Act, however, were more closely tied to the campaign by House Democrats to end the Reconstruction and the use of troops to sustain Republican regimes in the South. ${ }^{\mathbf{9}}$ Supporters of the Act relied on the propositions that Congress alone had the power to dictate the manner and circumstances in which troops could be used domestically in peacetime ${ }^{94}$ and that such statutory authorizations should be strictly construed..$^{95}$

The Act also provides that the Army and Air Force can be used on the basis of an express constitutional authorization. This language reflects a compromise reached in the debate over the Act. ${ }^{96}$ It is a meaningless proviso since the Constitution does not expressly authorize such a use of troops. ${ }^{97}$

In any event, if the Constitution had provided the President with authority over a purely executive function, Congress could not disable the President from acting on the basis of it, whether the authorization was express or implied. ${ }^{98}$ But since the Constitution pro-

91. Id. at 3581 (remarks of Mr. Kimmel).

92. Id.

93. President Hayes had promised to end the Reconstruction in return for congressional support for the electoral commission report which elected him and also for the release of funds for the Irmy which had been blocked by the House, see $\mathrm{C}$. Woodward, Reunion AND Reicion 9, 175 (1966). However, the President had permitted the use of troops by federal and local law enforcement personnel to protect the rights of freedmen and to protect Republican regimes, see SEFToN, supra note 85, it 219, without acknowledging his responsibility for such actions by issuing a proclamation when troops were so used. Major goals of the l'osse Comitatus Act were to prevent such covert use of troops by the President and the undercutting of the promise to end the Reconstruction. By requiring that troops could only be used when expressly atthorized by Congress, the law precluded their use on the implied authorization of the statutes giving power to the marshals, supra note 82, and forced the president to follow the terms of the law in issuing a proclamation to disperse when troops were used to execute the laws.

91. See 7 Conc. Rrc. 4686 (1878) (remarks of Mr. Hewitt); 5 Conc. REc. 2113 (1877) (remarks of Mr. Atkins).

05. See 7 CoNi. REc. 4242, 4296 (1878) (remarks of Scnators Kernan and Teller).

916. The original draft of the Act would have limited the use of army or navy folces to express statutory authorizations, 7 CoNG. REc. 3586 (1878). Mention of naval forces was dropped, 7 Cons. Rec. 3877 (1878), presumably because the Act was a rider to an Army appropriations bill and also sought to block the use of the appropriation bill's funds for any use of troops which violated the terms of the Act. Republicans in the Senate sought to emasculate the Act by amending it to permit actions taken on the hasis of constitutional authorization as well, 7 Coxc. REc. 4240 (1878), and exciscd the word "expressly," 7 Cong. RIc. 4248 (1878). In conference the House leaders inisted that "cxpressly" be replaced, see 7 CoNG. REC. 4686 (1878) (remarks of Mr. Hewitt), although they were either unable to have reference to constitutional atlthorizations deleted or felt that it was meaningless if modified by the word "expressly."

17. See 7 Coxi. Rec. 4296 (1878) (remarks of Sell. Edmunds).

98. Sec Myers v. United States, 272 U.S. 52 (1926). The Myers Court held that the Congress could not limit the power of the President to remove a federal official serving in a purely executive function, despite the fact that such removal power was implicd rather than expressly granted to the President in the Constitution. 
vides Congress with the power to control military intervention in domestic affairs, ${ }^{99}$ the President's actions can be limited to the express terms of a statutory authorization. ${ }^{100}$

The Nixon Administration has asserted that lack of any mention of restrictions on the Navy or Marine Corps in the Act means that these branches may be used to execute the laws, as the President wishes, ${ }^{101}$ under the theory that inherent presidential power exists where Congress has left a vacuum. ${ }^{102}$ Such a claim ignores the fact that the restrictions discussed in the previous sections apply to all the services. The lacuna of the Posse Comitatus Act merely means that the use of the Navy or Marines to execute the laws other than as provided by statute is not a criminal offense. Thus, for example, the recent commitment of Marine Corps personnel to assist police in New Orleans ${ }^{103}$ cannot be sustained, since Congress has prohibited the use of any military forces to assist local authorities unless there are both a request from the state government or a violation of federal law, and the issuance of a proclamation by the President. ${ }^{104}$

The Posse Comitatus Act provides an appropriate balance between the need for swift executive action in times of domestic turmoil and the need to check and contain the use of military power in civil affairs. Its impact can be seen by examining the use made by the current Administration of the Economy Act of 1932 as a vehicle for evading the requirement for a proclamation to disperse. The relevant portions of the Act provide that:

Any executive department ... of the Government ... may place orders with any other such department ... for materials, supplies, equipment, work, or services, of any kind that such requisitioned Federal agency may be in a position to supply or equipped to render..$^{105}$

99. See p. 133 supra.

100. Humphrey's Executor v. United States, 295 U.S. 602 (1935); Little v. Barreme,

6 U.S. (2 Cranch) 170 (1804). But cf. Mitchum v. Foster, 407 U.S. 225, 236-38 (1972).

101. Compare 37 Fed. Reg. 3637 (1972) (to be codified at 32 C.F.R. $\$ 215.4(\mathrm{~b})$ ), with 32 C.F.R. $\$ 187.4($ b) (1969).

102. See pp. 136-37 supra.

103. See note 126 infra. If such action had been taken by Army or Air Force personnel, it would have violated the Posse Comitatus Act, see Wrynn v. United States, 200 F. Supp. 457 (E.D.N.Y. 1961).

104. See pp. 139-4l supra. The failure of Congress to provide authority for the President to use troops to execute local laws without a request from the governor or legislature and without any simultaneous violation of federal laws or rights does not bring the action under an inherent power theory, see pp. 134-37 supra, since this is not a power given to the federal government, $c f$. U.S. Consr. amend. $X$. Here again, if federal interests were involved, nothing would stop the President from providing military forces to stop the sniping except his own political reticence to issue a proclamation.

105. 31 U.S.C. $\$ 686(1970)$. 
The Nixon Administration has interpreted this provision to provide authority for the use of federal troops to assist federal agencies in their law enforcement roles. Troops in large numbers were used under this rationale to serve as guards on American domestic air carriers during the latter half of $1970^{106}$ and to process and deliver the mail in New York City during the postal strike of March $1970 .{ }^{107}$ No proclamation was issued in the first case, while a proclamation of national emergency was issued in the second ${ }^{108}$ in order to call up reservists to carry out the mission. ${ }^{109}$

The Economy Act cannot be used as the basis of such actions since it does not provide express authorization for such uses of troops. It was the interpretation of just such a general statute which Congress sought to eliminate as an authorization for the use of troops in a law enforcement role when it passed the Posse Comitatus Act. ${ }^{110}$ This would not have disabled the President from taking such actions, but it would have required him to provide notice that he was so acting. The provision of notice is particularly important in cases where the armed military personnel carry out their roles in the civilian sector in mufti. When troops in large numbers are used in such roles, the press can provide some notice of the action. ${ }^{111}$ However, the use of such troops under the Economy Act could quickly devolve into use of small details of men for law enforcement or intelligence roles-just as troops were used as part of law enforcement efforts following the Civil War. ${ }^{112}$

The Nixon Administration seems to have conceded that its use of troops under the Economy Act was a potential violation of the Posse Comitatus Act since it does not now list it as a statutory exception to the prohibitions of the Act.13 On the other hand, while one might

106. See N.Y. Times, October 3, 1970, at 56, col. 1.

107. See Letter from Winton Blount to Melvin Laird, March 22, 1970, in Blaustein S Koritzinsky, supra note 1 , at VI-107.

108. Proclamation No. 3972, 35 Fed. Reg. 5001 (1970).

109. 10 U.S.C. $\$ 673$ (1970) requires a state of national emergency before reserve forces can be called to active duty. The President also needed to call up National Guard units to meet the manpower needs of the military. However, the President could not federalize National Guard troops (as opposed to rescrvists) unless he was "unable with the regular forces to execute the laws of the United States," 10 U.S.C. \$ 3500 (1970). Hence, in Exec. Order No. 11519, 35 Fed. Reg. 5003 (1970), he characterized the action as being taken to prevent the lostmaster General from violating laws requiring him to sce that certain postal functions were carried out, citing 39 U.S.C. $\$ \$ 707(a), 5102,6001, \& 6101$ (1964).

110. See p. 142 supra.

111. See, e.g., N.Y. Times, October 3, 1970, at 56, col. 1 .

112. See pp. 142-43 supra.

113. 37 Fed. Reg. $3637-38$ (1972) (to be codified at 32 C.F.R. $\$ 215.4(c)(2)$ ). Note however that two carlier Presidents used troops to protect the mails from robbery without issuing proclamations: President Harding used 1000 troops to protect mail trains 
disagree with the policy of using troops-in uniform or mufti-to assist the Secret Service in its protective functions, ${ }^{114}$ this use was clearly intended by Congress in the passage of House Joint Resolution 1292 in $1968 .{ }^{115}$ Hence it is a valid statutory exception to the Posse Comitatus Act.

\section{Gloss on Executive Power}

Despite the extensive statutory regulation of presidential use of troops, there remains the theory of Justice Frankfurter that a gloss on the executive power resulting from a "systematic, unbroken, ex.ecutive practice, long pursued to the knowledge of Congress and never before questioned"116 might permit the use of troops by the President in the face of congressional restrictions. The use of troops by the President to execute the laws, however, does not fall into this pattern. It has been the subject of considerable tension between Congress and the White House, and individual Presidents have acted inconsistently with such a theory. For example, although President Cleveland acted on an inherent power theory in suppressing the Army of the Commonweal in $1893,{ }^{117}$ he issued a proclamation the following year pursuant to statute while using troops to enforce similar

in 1921, see N.Y. 'Times, Nov. 9, 1921, at I, col. 3; President Coolidge used 2500 troops in a similar role in 1926, see N.Y. Times, October 21, 1926, at 10, col. 2. But see JAG 370.6, Sept. 14, 1925, cited in Furman, supra note 54, at 106 n.131.

114. Troops have been detailed to assist the Secret Service on covert intelligence and law enforcement missions on a number of occasions, eight of them involving sig: nificant numbers of troops. In August 1968, 6000 regular troops were pre-positioned in Chicago under the direction of the Secret Service during the Democratic National Convention, see Richrs in Conflict 103, 116 (Bantam ed. 1968) (study report of the National Commission on the Causes and Prevention of Violence). However, only a fraction of these were actually used-on covert intelligence missions. See Hearings on Federal Data Banks, Computers and the Bill of Rights, Before the Subcomm. on Constitutional Rights of the Senate Comm. on the Judiciary, 92nd Cong., Ist Sess. 1293, 1751 (1971) [hereinafter ciled as Hearings].

Troops were used during each of President Nixon's inaugurations under the direc* tion of the Secret Service, see Rights IN CONCORD 108 (G.P.O. 1969) (itudy report of the National Commission on the (auses and Prevention of Violence); SCHLorir.rBeck and Mansine, supra note 63 , at 8 ; N.Y. Times, Jan. 18,1973 , at 35 , col. 3 .

Troops were used on three occasions to garrison the White House during anti-war demonstrations: in November 1969, May 1970, and May 1971, see, e.s., Wash. Post, May 3, 1971, at 18, cols. 2 \& 3; Demonstrations and Dissent in the Nation's Capital (Dep't of Justice Press Release, June 8, 1970), in Hearings, supra at 1384.

Troops were also used under the control of the Secret Service during the 1972 Democratic and Republican National Conventions. See N.Y. Timcs, July 9, 1972, at 1, col. 2; id., August 18, 1972, at 26, col. 6 .

115. See 114 CoNG. Rec. I6170 (1968) (remarks of Sen. Javits on H.R.J. Res. 1292, 90th Cong., 1st Sess. $\$ 2$ (1968), 82 Stat. 170). Note that there is no requirement in the Resolution for the use of an executive order or proclamation to provide notice of such use of troops.

116. Youngstown Sheet and Tube v. Sawyer, 343 U.S. 579, 610-11 (1952) (Frankfurter, J., concurring).

117. See Rich, supra note 2 , at 204. 
court orders in the Pullman Strike. ${ }^{11 s}$ And although President Johnson failed to issue a proclamation when he used troops to protect the Pentagon from demonstrators in $1967,{ }^{119}$ during the Detroit riot of 1967 he had justified his order federalizing the Michigan National Guard in the requisite proclamation which stated that the riot endangered federal property. ${ }^{120}$ During the 1968 riot in Washington, D.C., he again issued the necessary proclamation when he used troops to protect the functions of the federal government from violence or other interference. ${ }^{121}$ Hence the practice has not been systematic, has been frequently broken, and has been the object of congressional criticism. ${ }^{122}$

\section{The Need for Congressional Action}

Congressional action to rationalize the relevant legislation is needed in order to eliminate the ambiguities and lacunae.

\section{A. Proclamation to Disperse}

The deterrent or warning function of the proclamation to disperse has never been very effective. ${ }^{123}$ Particularly in cases of political dissent or racial riots, the moral power of the office of the Presidency or the mere threat of military force has not proved a deterrent. President Johnson acknowledged that ineffectiveness by generally waiting only sixty seconds before ordering troops committed after he had issued a proclamation ordering racial rioters to disperse. ${ }^{124}$ Such constructive notice, although it may be strictly legal, ${ }^{125}$ obviates any minimal deterrent function which a proclamation might have.

118. See note 58 supra.

119. See note 8 supra.

120. Proclamation No. 3795,3 C.F.R. 68 (1967).

121. Proclamation No. 3840, 3 C.F.R. 35 (1968). See pp. 140-41 supra \& text accompanying notes $123-25$ infra.

122. See pp. 142-43 supra.

123. The proclamation has often incited, rather than suppressed, opposition to the law. See F. Wilson, supra note 36 , at 41 (account of the incendiary impact of President Jefferson's proclamation, 1 Richardson, supra note 2, at 450 , during the land embargo controversy in Vermont). President Fillmore found that the proclamation provided sufficient notice for the lawbreakers to flee and avoid capture, 5 Richakdson 105.

124. See, e.g., l'roclamation No. 3840, 3 C.F.R. 35 (1968), dated 4:02 pm on April 5, 1968, ordering rioters in Washington, D.C., to disperse. Exec. Order No. 11403, 3 C.F.R. 107 (1968), was signed one minute later. It ordered the commitment of federal troops, stating in part: "WHERE.AS the conditions of domestic violence and disorder described ... continuc, and the persons engaging in such acts of violence have not dispersed ...."

125. Cf. Lapeyre v. United States, 84 U.S. (17 Wall.) 191, 200 (1872). However, faced with an on-going serious riot, prudence dictates that the President act quickly if it becomes evident that the proclamation to disperse would be ineffective in suppressing the disorder. The same argument would not hold where the President faced a situation of potential violence or where the disobedience to the law did not demand an immediate military response. 
The need for a device such as the proclamation remains strong, however. The present policy of ignoring the proclamation requirement in certain circumstances has serious shortcomings. For example, it is not clear whether the President approved the use of Marine Corps personnel to assist municipal officials in suppressing a sniping incident in New Orleans in $1973^{126}$ since no proclamation was issued. A requirement that the President formally notify the public whenever he used troops in a law enforcement role would have eliminated any doubt whether the action was taken with the approval of the President or simply on the initiative of local military commanders, whether the state officials had asked for help or whether the President was bypassing them, whether the Marines have become a national police reserve force or whether this was an isolated incident. At the same time, a proclamation by the President would have indicated a request for assistance from the state government or the determination that state officials were unable to protect some federal interest which was also involved. Such notice would have provided the citizens of Louisiana with some indication of the effectiveness of state law enforcement personnel and equipment and the potential for federal assistance in the future to fill gaps that existed in them.

An inquisitive press might ferret out these facts, but such essential judgments on the conduct of government officials should not have to depend solely on the fourth estate for necessary information. Moreover, there may be a significant time lag before the facts of an incident are revealed. For example, two years elapsed before it was revealed that Army personnel served in covert intelligence roles during the demonstrations at the 1968 Democratic National Convention in Chicago..$^{12 \pi}$

Despite the need for a proclamation to provide notice of the President's actions, the political risks involved in such an acknowledgment of responsibility have led many Presidents to seek means of circumventing the requirement. ${ }^{128}$

Congress should amend 10 U.S.C. $§ 334$ to require the issuance of a proclamation commanding obedience to the law $w^{129}$ or an executive

126. N.Y. Times, Jan. 9, 1973, at 22, cols. $2 \& 3$.

127. See Hearings, supra note 114 , at 1294,1751 .

128. See Rich, supra note 2, at 33 (tactics used by President Jefferson to circumvent the requirement); Morris, Andrew Jackson, Strikebreaker, 55 AMER. Hist. RLv. 61 (1949) (failure of Jackson to issue proclamation when troops were committed in responsc to request from Maryland legislature).

129. Requirement of a proclamation to disperse is inappropriate in many circumstances, e.g., when the President faces only the prospect of violence, see note 71 supra. 
order whenever federal military personnel are used to execute the law in the civilian sector, except in circumstances specifically exempted by Congress. ${ }^{130}$ This would remove any question that a proclamation must be promulgated before troops, including those acting under the direction of the Secret Service, are employed to execute the law. ${ }^{13 t}$ It would reaffirm the concept that the use of military force in domestic affairs is an extraordinary event which should not take place without the President's express permission and a formal acknowledgment of that action. This change in the law would preclude the covert use of troops in law enforcement roles in the civilian sector. ${ }^{132}$

The law should permit the President to issue an Executive Order rather than a proclamation ${ }^{133}$ to disperse in circumstances in which he is not confronting massed violations of the law but finds it necessary to reinforce a federal agency in its law enforcement activities, e.g., the use of troops to assist the Secret Service in its protective duties. The purpose is not to expand presidential power in this area, but rather to preclude the covert use of troops. Such Executive Orders would alert the public and the Congress to the intervention of the military in such roles and highlight the need for civil alternatives. Present practice provides no such notice. ${ }^{134}$

\section{B. Posse Comitatus Act}

Congress should include the Navy and Marine Corps within the prohibition of the Posse Comitatus Act. This would remove any question about the use of the Marines by the President in a local law enforcement role and would stop private interventions by local Marine commanders. ${ }^{135}$ No policy reasons can be advanced for exempting

130. Such a requirement could exempt the use of military police in law enforcement roles involving armed forces personnel in the vicinity of military bases. But see 18 U.S.C. $\$ 1384(1970)$.

131. See pp. 145-46 supra.

132. It would also make it clear if local military personnel were acting on their own or the President's initiative when they assisted local authorities.

133. A proclamation is directed at the "insurgents" or at the public in general, while an Executive Order would direct a cabinet officer to take certain steps to utilize troops in the civil sector. Notice is provided by publication in the Federal Register, see, e.g., Exec. Order No. 11519, 35 Fed. Reg. 5002 (1970).

134. The proclamation requirement currently applies only to actions taken under the authority of 10 U.S.C. $\$ \$ 331-33(1970)$. H.R.J. Res. 1292 does not contain such a proclamation requirement. A proclamation to disperse was not used when troops were committed pursuant to 31 U.S.C. $\$ 686$ (1970), see pp. $144-45$ supra.

135. The January 1973 commitment of troops in New Orleans may have been the result of the initiative of a local Marine commander. Former General Counsel of the Army Alfred Fitt reported to the author that a group of Marines assisted local law enforcement personnel in 1963 in Mississippi on their own initiative. If the President cannot control the initiatives of local troops, certainly the public should have clear 
these forces from the coverage of the Act. The present gap in coverage reflects the legislative tactics used in passage of the Act in 1878 rather than any decided congressional policy to exempt those services. ${ }^{136}$

At the same time the mention of a constitutional exception to the prohibition of the Act should be deleted. It serves only to confuse interpretation of the Act without presenting any real exception to its prohibitions. ${ }^{137}$

\section{Other Legislation}

Congress should also amend 18 U.S.C. $\$ 592$, which currently prohibits the use of troops at polling places except to repel the armed enemies of the United States, ${ }^{138}$ by restoring the original wording of this provision which permitted the use of troops to keep peace at the polls. ${ }^{139}$ This would eliminate the possibility that a President would be unable to respond to a state request for assistance to quell a disorder which was disrupting the polling process. ${ }^{140}$ The requirement that the President issue a proclamation in such circumstances and the prohibitions against military interference in the right to vote ${ }^{141}$ limit the potential for abuse of this procedure.

To remove any questions about the authorization contained in the Economy Act of $1932^{142}$ Congress should amend it to indicate that troops cannot be used under its provisions in law enforcement roles. This action would rationalize the statutory authorizations by making it clear that such law enforcement activities can only be undertaken under the express military provisions. ${ }^{143}$

\section{Judicial Review}

Violation of the existing or amended statutes by a President poses a delicate problem of judicial review. Although the Supreme Court has been reluctant to review the discretion of a President in a Guarantee Clause situation, ${ }^{144}$ it has held that the question of violation

notice of this by establishing a policy of issuing a proclamation whenever the President initiates such an intervention. Private interventions would then be highlighted by the lack of such a proclamation.

136. See note 96 supra.

137. Id.

138. See note 63 supra.

139. Act of February 25,1865 , ch. $57, \$ 1,13$ Stat. 437 .

140. See, e.g., M: Aldrich, History of THE United States Marine Coris 118 (1875).

141. 18 U.S.C. $\$ \$ 593,594$ (1970); 42 U.S.C. $\$ 1972$ (1970).

142. See pp. 14446 supra.

143. See 10 U.S.C. $\$ \$ 331-34$ (1970).

144. See Baker v. Carr, 369 U.S. 186, 213 (1962); Luther v. Borden, 48 U.S. (7 How.) 1 (1849); Martin v. Mott, 25 U.S. (12 Wheat.) 19 (1827). But see Baker v. Carr, 369 U.S. at 243 (Douglas, J., concurring). 
of statutory strictures on presidential military action is justiciable. ${ }^{145}$ Justice Frankfurter noted in his concurring opinion in Youngstown:

To deny inquiry into the President's power in a case like this, because of the damage to the public interest to be feared from upsetting its exercise by him, would in effect always preclude inquiry into challenged power, which presumably only avowed great public interest brings into action. ${ }^{146}$

Where the Court felt competent to judge the necessity behind executive action, i.e., in situations where violence and disorder did not require a purely military judgment on a threat to peace, it has reviewed the claim of necessity by the Executive. ${ }^{147}$ In Sterling $v$. Constantin ${ }^{148}$ the Court held that a governor had improperly used his power to declare martial law when he utilized it to prevent the imposition of federal oil production regulations in his state. In the course of its decision, the Court ruled that "the allowable limits of military discretion, and whether or not they have been overstepped in a particular case, are judicial questions." 149 Although the circumstances in this case are somewhat extreme, the principle involved can be applied to actions taken by the President. 150

Where a purely military judgment is involved, and where the problem of military command and control in an emergency is at issue, the Court has held that "the need for finality in the political determination" is "dominant." 151 It seems likely that in a situation involving ongoing violence the Court would decline to review the propriety of executive action except when faced with "an act of mere oppression, an arbitrary fiat that overleaps the bounds of judgment."152

A justiciable claim might arise in the course of gubernatorial opposition to federal intervention to enforce state laws, ${ }^{153}$ in a defense to a criminal charge of resisting a lawful arrest by military personnel during a disorder, ${ }^{154}$ as an element in a suit for damages resulting

145. See Youngstown Sheet and Tube v. Sawyer, 343 U.S. 579 (1952); Little v. Barreme, 6 U.S. (2 Cranch) 170 (1804); cf. Sterling v. Constantin, 287 U.S. 378 (1932). 146. 343 U.S. at 596.

1.47. See, e.g., Sterling v. Constantin, 287 U.S. 378 (1932); Ex Parte Milligan, 71 U.S. (4 Wall.) 2 (1866); cf. A Quaker Action Group v. Hickel, 421 F.2d 1111, 1118 (D.C. Cir. 1970).

148. 287 U.S. 378 (1932).

149. Id, at 401 .

150. See Panama Refining Co. v. Ryan, 293 U.S. 388, 446 (1935) (Cardozo, J.,

dissenting).

151. Baker v. Carr, 369 U.S. 186, 213 (1962).

152. Panama Refining Co. v. Ryan, 293 U.S. at 446 (Cardozo, J., dissenting).

153. See Alabama v. United States, 373 U.S. 545 (1963).

154. See Stewart v. United States, 27 Fed. Cas. 1339 (No. 16,401a) (D.C. Crim. Ct. 1857). 
from government action or inaction in the course of a disorder, ${ }^{165}$ or in a defense to a charge of violation of a lawful military order by a serviceman who maintained that obedience would have subjected him to the criminal sanctions of the Posse Comitatus Act. ${ }^{150}$

\section{Conclusion}

Action by Congress is necessary if it is to prevent the continued erosion of its power to control the use of military force in domestic affairs. The general aggrandizement of the power of the President might appropriately be checked in this area where the claim of Congress is strong and that of the President is based on a faulty interpretation of the controlling statutes and a misconception of the constitutional precedents. Certainly we cannot tolerate the paradoxical situation in which the President enforces some laws with the muzzle while honoring others in the breach.

155. See Valdez v. Black, 466 F.2d 1071 (10th Cir. 1971); United States v. Chalk, 441 F.2d 1277 (4th Cir. 1971); Mitchel v. Harmony, 54 U.S.'(13 How.) 115 (1851).

156. Cf. Board of Educ. v. Allen, 392 U.S. 236 (1968). But see Martin v. Mott, 25 U.S. (12 Wheat.) 19 (1827). 